\title{
Intervention pursuant to article 4(h) of the Constitutive Act of the African Union without United Nations Security Council authorisation
}

\author{
Gabriel Amvane* \\ Doctor of International Law, Strasbourg, France
}

\begin{abstract}
Summary
Article 4(h) of the Constitutive Act of the African Union (AU) establishes the right of the Union to intervene in a member state to prevent grave violations of human rights. It does not state whether the $A U$ should request prior authorisation from the United Nations (UN) Security Council, leading to many interpretations. Many articles were written on this issue at a time when the $A U$ and the Security Council were not in confrontation. However, the situation has changed since the controversy over the arrest of President Al Bashir of Sudan, and the intervention by NATO in Libya in 2011. The AU's right of intervention may be the next controversy. This article examines the question whether the AU could implement military intervention in a member state without authorisation by the Security Council. The article initially states that, in principle, the $A U$ needs authorisation in accordance with article 53 of the Charter of the UN. After further analysis, the article recognises that, under certain circumstances, the AU could implement such intervention without prior authorisation by the Council. The article analyses the legality and legitimacy of such action.
\end{abstract}

Key words: African Union; United Nations; military intervention; authorisation 


\section{Introduction}

Since the adoption of the Constitutive Act of the African Union (AU), numerous articles have been written on article 4(h) of the Act, ${ }^{1}$ which presents what appears to be an innovative norm in international law. Intervention for humanitarian purposes has been debated ethically and morally. ${ }^{2}$ However, the $A U$ is the first organisation to insert it in a normative charter. ${ }^{3}$ Indeed, article $4(\mathrm{~h})$ establishes 'the right of the Union to intervene in a member state pursuant to a decision of the Assembly in respect of grave circumstances, namely, war crimes, genocide and crimes against humanity'. Three years later, the AU added amendments to the Constitutive Act to extend the right of intervention to 'a serious threat to a legitimate order to restore peace and stability to the member state of the Union upon the recommendation of the Peace and Security Council'. ${ }^{4}$ It is clear that by intervention, the Constitutive Act of the AU means military intervention authorised by the AU Assembly and implemented by African forces in an African state, ${ }^{5}$ where at least one of the grave circumstances mentioned above exists. This intervention is unilaterally decided upon by the $\mathrm{AU}$, and not requested by the state concerned, otherwise such intervention would not be within the scope of article 4(h), but within that of article $4(\mathrm{j}),{ }^{6}$ which is deployed at the request of the state faced with war crimes, genocide or crimes against humanity. The debate around article 4(h) results from its supposed conflict with some measures of the United Nations (UN) Charter, namely, articles 2(4) and 53. Article 2(4) states:

All members shall refrain in their international relations from the threat or use of force against the territorial integrity or political independence of any state, or in any other manner inconsistent with the Purposes of the United Nations.

The UN Charter defines two exceptions to this prohibition: selfdefence, in article 51; and enforcement measures decided upon by the Security Council in chapter VII. Moreover, the Security Council may not only decide upon such measures and call on regional

1 AA Yusuf 'The right of intervention by the African Union: A new paradigm in regional enforcement action' (2003) 11 African Yearbook of International Law 3-21; B Kioko 'The right of intervention under the African Union's Constitutive Act: From non-interference to non-intervention' (2003) 85 IRRC 807-826; D Kuwali 'Art 4(h)

+ R2P: Towards a doctrine of persuasive preventive to end mass atrocity crimes' (2008) 3 Interdisciplinary Journal of Human Rights Law 55-85.

2 See, eg, JL Holzgrefe \& R Keohane (eds) Humanitarian intervention: Ethical, legal and political dilemmas (2003)

3 AP Rodt 'The African Union mission in Burundi' (2012) 14 Civil War 375.

4 African Union 'Protocol on Amendments to the Constitutive Act of the African Union' 11 July 2003 para 4(h).

5 With the exception of Morocco, which left the Organisation in 1985 due to the position of the OAU on the affairs of Western Sahara in 1982

6 Art 4(j) concerns 'the right of member states to request intervention from the Union in order to restore peace and security'. 
organisations for their implementation, but may also authorise those regional organisations to initiate enforcement action. Without such authorisation by the Security Council, it is claimed that regional organisations may not undertake enforcement action. Article 53 of the UN Charter made this clear by stipulating that '[n]o enforcement action shall be taken under regional arrangements or by regional agencies without the authorisation of the Security Council'.

The problem arises because of the fact that the Constitutive Act does not state whether the AU should request authorisation from the Security Council before being able to intervene in accordance with article 4(h). ${ }^{7}$ The question then arises whether the obligation in article 53 of the UN Charter applies to the $\mathrm{AU}$ when exercising its right of intervention for humanitarian purposes in a member state according to article 4(h). If the answer to this question is in the affirmative, it may be asked whether there is any limit to that obligation. In other words, what would be the position of the AU if the Security Council hesitates or fails to authorise an intervention in time while it has been proven that war crimes, genocide or crimes against humanity are taking place in an African state? Is there any legality or legitimacy for the $A U$ to intervene to stop mass violations of human rights without express prior authorisation by the Security Council?

As stated previously, this question has been debated since the adoption of the AU Constitutive Act. However, most of the articles on the issue were written before 2009. Up to that time, the relationship between the two organisations was cordial. However, since 2009, two problems have arisen between the Security Council and the AU. The first related to the matter of the International Criminal Court (ICC). In 2005, the Security Council authorised the ICC to investigate ${ }^{8}$ alleged crimes in Darfur on the basis of article 13(b) of the Rome Statute. The Council refused to comply with the request of the $A U$ regarding delaying the prosecution of President Al Bashir. The same was the case with the prosecution of President Uhuru Kenyatta of Kenya. Since 2009, the AU has asked its member states to refrain from co-operating with the ICC, ${ }^{9}$ in other words, with the Security Council which mandated the ICC.

The second problem arose with the intervention in Libya, authorised by the Security Council and implemented by NATO. The $\mathrm{AU}$ was opposed to this intervention ${ }^{10}$ and the way in which it was

7 Yusuf (n 1 above) 14.

8 Resolution of the Security Council S/RES/1593 (2005), adopted on 31 March 2005.

9 Thirteenth ordinary session of the Assembly, Decision on the Meeting of African States Parties to the Rome Statute of the International Criminal Court, 1-3 July 2009. See Assembly/AU/Dec.245(XIII) Rev 1 para 10.

10 See PSC/PR/COMM.2(CCLXV), Communiqué of the Peace and Security Council on 10 March 2011, para 6, where the PSC 'reaffirms its strong commitment to the respect of the unity and territorial integrity of Libya, as well as its rejection of any foreign military intervention, whatever its form'. 
implemented, as recounted by South African President Zuma before the Security Council in 2012. ${ }^{11}$ Article 4(h) may well be the next confrontation between the two organisations.

This article argues that, even if the principle is that the AU needs authorisation by the Security Council to exercise its right to intervene according to article $4(\mathrm{~h})$, there may be certain circumstances under which it could intervene without authorisation. The article also recognises the fact that such intervention may be accomplished only if the Council has not decided whether to give authorisation, which means that the $\mathrm{AU}$ may not intervene if the Council expressly refuses to authorise the intervention.

\section{Foundations of the centralisation of force}

Chapter VIII of the UN Charter is the result of lengthy negotiations between partisans of regionalism and partisans of universalism. ${ }^{12}$ The first universal organisation in charge of issues of international peace and security was the League of Nations. This organisation, created shortly after World War I, was hostile towards regional organisations. Such hostility could have resulted from several factors, as explained by Villani. ${ }^{13}$ The founding states of the League of Nations were aware of the fact that World War I mainly had been triggered by opposition between two groupings, the allied powers and the central powers. They considered it important to prevent the repetition of such a war, by refusing to mention any regional organisation in the Covenant of the League of Nations. President Wilson of the United States made it clear in the following terms: 'There can be no leagues or alliances or special covenants or understandings within the general and common family of the League of Nations. ${ }^{14}$ This completely excluded regional organisations from the system of the League of Nations. ${ }^{15}$ Nevertheless, the President introduced an amendment to the

11 Echoing the AU, President Zuma stated: 'Critical to building a stronger relationship will be to avoid a situation such as that which transpired during the conflict in Libya. The AU's plan was completely ignored in favour of the bombing of Libya by NATO forces.' See Statement of President Zuma before the Security Council on the 6702nd meeting of the Council S/PV.6702 3.

12 A Acharya 'Norm subsidiarity and regional orders: Sovereignty, regionalism and rule making in the Third World' (2011) 55 International Studies Quarterly 97.

13 U Villani 'Les rapports entre l'ONU et les organisations régionales dans le domaine de maintien de la paix' (2001) 290 Collected Courses of the Hague Academy of International Law 239.

14 President Wilson's Address at the Metropolitan Opera House, New York, 27 September 1918, http://query.nytimes.com/gst/abstract.html?res=F20916F73E 5511738DDDA10A94D1405B888DF1D3 (accessed 20 December 2013).

15 JM Yepes 'Les accords régionaux et le droit international' (1947) 71 Collected Courses of the Hague Academy of International Law 259. 
Covenant to take into account the Monroe Doctrine. ${ }^{16}$ However, recognition of the Monroe Doctrine was not enough to counterbalance the global spirit of the Covenant since it appeared as a mere exception to article 20 of the Covenant.

In addition, the founding states of the League of Nations were also aware of the fact that the League represented the first attempt at creating an international organisation that could impose its authority on sovereign states. It certainly would have been difficult if the League had to face not only the sovereignty of states, but other international organisations as well. ${ }^{17}$ For these reasons, they did not envisage any relationship between the League and regional organisations. However, many regional organisations were created during the lifetime of the League, ${ }^{18}$ but it was not possible for the universal organisation to take advantage of these organisations.

Therefore, when it came to draft a charter for the new universal organisation, the UN, some deemed it necessary to define the relationship between the UN and regional organisations. The debate was no longer about the existence of regional arrangements and their relationship with the global system, but on the role that these arrangements would play under the UN system, and the quality of the relationship that would exist. As Borgen commented about the US Secretary of State, Mr Hull, who favoured the global system: 'Hull did not deny that regional arrangements could exist, but believed that they "should be subordinate to a strong centralised organisation"'. ${ }^{19}$

The debate at the San Francisco conference consisted of two groups: those who were still attached to a centralised system and those who were opposed to the supremacy of the Security Council over regional arrangements. ${ }^{20} \mathrm{~A}$ compromise was found, as reflected in chapter VIII of the UN Charter. Article 52 of the Charter ${ }^{21}$ favours regional organisations for peaceful settlements. Contrary to articles 20 and 21 of the Charter of the League of Nations, which limited the existence of regional organisations, article 52 of the UN Charter states that nothing in the Charter precludes the existence of regional arrangements or agencies. The counterpart of this recognition,

16 Art 21 of the Covenant of the League of Nations resulting from that amendment stated: 'Nothing in this Covenant shall be deemed to affect the validity of international engagements, such as treaties of arbitration or regional understandings like the Monroe doctrine, for securing the maintenance of peace.'

17 Villani (n 13 above) 240.

$18 \mathrm{Eg}$, the treaty to avoid or prevent conflicts between American states (Gondra Treaty); the Treaty of Mutual Assistance of 1923 (approved by the Assembly of the League of Nations).

19 CJ Borgen 'The theory and practice of regional organisation intervention in civil wars' (1994) 26 New York University Journal of International Law and Politics 799.

20 Latin American states were particularly on top of this position. However, all the defenders of regionalism did not have the same interests and were not coordinated to defend their views.

21 Art 52 of the UN Charter states: 'Nothing in the present Charter precludes the existence of regional arrangements or agencies for dealing with such matters relating to the maintenance of international peace and security ...' 
however, is found in article 53 of the UN Charter which forbids any enforcement action by a regional organisation unless authorised by the Security Council. This results from chapter VIII, that all regional organisations, the AU included, need authorisation by the Security Council to exercise enforcement actions. Member states of the UN kept their right to self-defence as defined in article 51 of the Charter. But what does the Charter mean by enforcement action? Is the right of intervention affected by that prohibition?

\section{The right of intervention of the $\mathrm{AU}$ and enforcement actions}

The meaning of 'enforcement action' has evolved since the adoption of the Charter in 1945. Goodrich, Hambro and Simons show that during the debate at San Francisco, 'enforcement action was intended to mean any and all measures the Security Council was authorised to take under articles 41 and $42^{\prime 22}$ of the UN Charter. Yet, article 41 is related to non-military actions, which mostly is known by the term 'embargo'. These actions 'may include complete or partial interruption of economic relations and of rail, sea, air, postal, telegraphic, radio, and other means of communication, and the severance of diplomatic relations' ${ }^{23}$ Only article 42 concerns military actions. However, today we can agree with Borgen that 'practice has evinced a much more restricted interpretation of "enforcement action"'.24 The Security Council, itself, opted for the same interpretation. The first issues were related to the Organization of American States (OAS). This regional organisation imposed collective economic measures against the Dominican Republic in 1960. The same occurred in the case of Cuba in 1962. The Security Council was then consulted on whether the OAS could legally take collective economic measures against a member state of that organisation without authorisation by the Council. Although the Soviet Union initially argued that such a measure required the approval of the Council, it was finally concluded that article 53 did not apply to nonmilitary measures pursuant to article 41.25 This position subsequently became the rule, including as far as African regional organisations were concerned.

In March 2009, under pressure from civilian opposition and armed forces, President Marc Ravalomanana of Madagascar resigned.

22 L Goodrich et al Charter of the United Nations: Commentary and documents (1969) 365 .

23 Second sentence of art 41 of the UN Charter.

24 Borgen (n 19 above) 806.

25 S/PV.874, Record of the 874th meeting of the Security Council, 18 July 1960. Cuba brought the case before the Security Council. The United States and many other states were of the view that the OAS was the appropriate organisation to solve the problem in the first instance. The US first invoked the Inter-American Treaty of Reciprocal Assistance, signed at Rio de Janeiro on 2 September 1947, 
Mr Andry Rajoelina took the office of President of the Republic. The Security Council considered this change of government to be unconstitutional. ${ }^{26}$ Indeed, article 30 of the AU Constitutive Act states that '[g]overnments which shall come to power through unconstitutional means shall not be allowed to participate in the activities of the Union'. On the basis of this measure, the Security Council decided 'to suspend Madagascar from participating in the activities of the $\mathrm{AU}$ until the restoration of constitutional order in this country'. ${ }^{27}$ Before suspending Madagascar, the Council suspended Guinea and Mauritania. In all these cases, authorisation by the Security Council was not requested. As far as Madagascar was concerned, the Council requested the Chairperson of the Commission to work closely with all $\mathrm{AU}$ partners, including the Security Council. ${ }^{28}$ But this was not to seek authorisation; the PSC only wanted the Security Council to support the implementation of its decision.

The Economic Community of West African States (ECOWAS) already previously had proceeded in the same manner. In 1997, ECOWAS imposed a general and total embargo on Sierra Leone. It was subsequently requested that the Committee of Four 'solicit assistance from the United Nations Security Council to render these sanctions imposed universal and mandatory, in accordance with the United Nations Charter'. ${ }^{29}$ The Council was solicited not to give authorisation, but to render universal the implementation of sanctions that had already been decided upon by a regional organisation. The Security Council responded to that request by adopting Resolution 1132 (1997) in which it extended the sanctions imposed by ECOWAS on Sierra Leone. The Security Council had already responded in the same way in 1992 with the same regional organisation. ECOWAS imposed a general and complete embargo on all deliveries of weapons and military equipment to Liberia and requested the Council to extend these measures in a letter of 28 October 1992. By Resolution 788 (1992), the Security Council decided, according to chapter VII of the UN Charter, that all states should implement that

and the Charter of the Organization of American States, signed at Bogota on 30 April 1948, arguing that '[u]nder these treaties the American Republics contracted to resolve their international differences with any other American states first of all through the Organization of American States' (S/PV.874 para 97). The US also reminded that the 'UN Charter indicates to go to the regional organization first and to the United Nations as a place of last resort' (para 102). Apart from those legal arguments, and as some other states mentioned, the US maintained that to directly bring the differences before the Security Council would undermine the actions of the OAS, and some non-American states, such as the Soviet Union, could aggravate the situation (para 101).

26 PSC/PR/COMM.(CLXXXI), Communiqué of the Peace and Security Council on 20 March 2009, para 3.

27 Communiqué (n 26 above) para 4.

28 Communiqué para 5.

29 S/1997/695, letter dated 8 September 1997 from the Permanent Representative of Nigeria to the UN addressed to the President of the Security Council, Annex II and art 10. 
embargo. This confirmed the assertion that authorisation by the Security Council is needed only for military measures. However, article 4(h) of the AU Charter corresponds to military action, and cannot therefore be covered by the system of Article 41 of the UN Charter analysed above. Nonetheless, some military actions are deployed with the consent of the host state, or with its call for such intervention. This is the case with peacekeeping operations. This also applies to AU intervention pursuant to article 4(j) of its Constitutive Act.

The UN Charter did not expressly institute peacekeeping operations. These operations appeared at a time when the Security Council could not apply chapter VII of the Charter. The practice emerged with the Suez crisis in 1956. The Security Council could not take any action, as two permanent members (France and the United Kingdom) were involved in that crisis and it was evident that they would use their veto if the Council intended to adopt any resolution on the issue. Owing to the process established by Resolution 377 (V), the General Assembly could authorise the deployment of the military to observe the ceasefire. The United Nations Emergency Force (UNEF) was subsequently deployed in accordance with Resolution 998 (ES-I) of the General Assembly of 4 November 1956. The spirit of this first military peacekeeping procedure was guided by three main principles: the consent of the parties; neutrality; and the use of force only for selfdefence, as the Secretary-General described it. ${ }^{30}$ The ICJ subsequently considered that peacekeeping operations 'were not enforcement actions' $^{31}$ It is recognised in international law that regional organisations do not need authorisation to deploy peacekeeping operations. ${ }^{32}$ The AU may, therefore, deploy a peacekeeping mission without authorisation by the Security Council, as long as the host state consents to it.

Today, these principles have evolved sufficiently. A new generation of peacekeeping operations has emerged, with greater robustness, known as 'robust peacekeeping'. Force may be used to a greater extent than before. According to the Brahimi report, in implementing robust peacekeeping, military units must be capable not only of defending themselves, but also of defending other components and the mission's mandate, ${ }^{33}$ which often includes the protection of civilians. Furthermore, the report recommends that in particularly dangerous situations, rules of engagement 'should not force United Nations contingents to cede the initiative to their attackers' ${ }^{34}$ In

$30 \mathrm{~A} / 3943$, Report of the Secretary-General, Summary study of the experience derived from the establishment and operation of the Force, paras 153-193.

31 Certain Expenses of the United Nations, Advisory Opinion, 20 July 1962 (C) Reports 1962166.

32 A Orakhelashvili 'The legal framework of peace operations by regional organisations' (2007) 11 International Peacekeeping 119.

33 A/55/305-S/2000/809, Report of the Panel on United Nations Peace Operations, para 49.

34 As above. 
other words, peacekeepers should be allowed to attack only when the situation appears dangerous. In this context, should the AU request authorisation before deploying a robust peacekeeping operation? In actual fact, the answer is no. It is considered that peacekeeping still follows the same rules, even if some of the rules have evolved to adapt to the evolvement of armed conflicts. But even the current robustness of peacekeeping does not put peacekeeping and intervention under the same regime. The AU documents, themselves, establish a difference between peace support operations authorised by the Security Council in accordance with article 7(c) of the Protocol relating to the establishment of the Council, on the one hand, and intervention authorised by the AU Assembly in accordance with article 4(h) of the AU Constitutive Act, on the other. Peace support operations are not considered enforcement action, while intervention according to article $4(\mathrm{~h})$ is. This intervention is also different from intervention pursuant to article 4(j) of the AU Constitutive Act.

Article $4(\mathrm{j})$ establishes 'the right of member states to request intervention from the Union in order to restore peace and security'. In fact, it is easier to imagine that no authorisation would be necessary in the latter case than in the case of article 4(h). Here it is the host state that requests the intervention. This does not violate article 2(4) of the UN Charter which deals with the prohibition of the threat or the use of force against the territorial integrity or political independence of any state, since the host itself requested the intervention. This was the case in 2008 in the Comoros.

The Union of the Comoros faced many military crises since its independence in 1975, including some coups d'état. Due to the problems in the Comorian Island of Anjouan in 2007 and the negative consequences they could have had for the elections scheduled that year, the President of Comoros requested support from the AU. The Peace and Security Council first deployed the AU Electoral and Security Assistance Mission to the Comoros (MAES), with an initial period running from 13 May to 31 July $2007,35^{\prime}$ and extended thereafter. ${ }^{36}$ However, as the situation on the ground did not improve, the Comorian President requested stronger engagement by the AU. Consequently, the Assembly, in accordance with article 4(j), requested 'all member states capable of doing so to provide support to the Comorian government in its efforts to restore, as quickly as possible, the authority of the Union in Anjouan and to put an end to the crisis'. ${ }^{37}$ This decision led to the deployment of an African military intervention known as 'Operation Democracy' in Comoros. The operation was successful, and restored peace and security to the

35 PSC/MIN/Comm.1(LXXVII), Peace and Security Council Communiqué of 9 May 2007.

36 See PSC/PR/Comm(LXXXIV), Peace and Security Council Communiqué of 31 July 2007.

37 Assembly/AU/Dec.186 (X), Decision of the Assembly on the Situation in the Comoros, 10th ordinary session, 31 January-2 February 2008, para 3. 
Comoros, enabling MAES to achieve its goal. It is important to note that the AU Assembly did not request authorisation from the Security Council before this intervention. However, it would not be simple to establish a parallel with article 4(h). The intervention in the Comoros was authorised in accordance with article 4(j), which means that the intervention was requested and consented to by the host state and that there was no clash with article 2(4) of the UN Charter. This is not the case in the event of an intervention pursuant to article 4(h). The latter remains entirely under the ambit of the mechanism instituted by article 53 of the UN Charter.

\section{Principle of necessary and prior authorisation}

As outlined above, intervention pursuant to article 4(h) of the AU Constitutive Act corresponds to the 'enforcement action' defined in article 53 of the UN Charter. May the AU, therefore, ignore the mechanism of necessary authorisation as established by the UN? In actual fact, according to article 103 of the UN Charter, '[in] the event of a conflict between the obligations of the members of the United Nations under the present Charter and their obligations under any other international agreement, their obligations under the present Charter shall prevail'. This leads to the conclusion that, in principle, the AU has to respect article 53 of the UN Charter. The AU has to request authorisation from the Security Council when intervening in accordance with article $4(\mathrm{~h})$ of its Constitutive Act. This is the principle. On the face of it, the analysis could end here. ${ }^{38}$ However, many other questions may be raised if one wants to go further and get a more comprehensive analysis of the question. What did the AU intend when including this measure in its Constitutive Act? What would and should the AU do if there are war crimes, crimes against humanity or genocide on the ground and the Security Council does not provide timeous authorisation? Would the AU allow people to die because of technical problems at the Security Council? If the AU intervenes without Security Council authorisation, would such intervention be legal? The following analyses demonstrate that, in certain cases, the AU might intervene in accordance with article 4(h) without authorisation by the Security Council.

\section{Evolvement of international peace and security}

It mist be recognised that many measures in the UN Charter have evolved sufficiently. The Charter was written in 1945 during a

38 See, eg, G Amvane Les rapports entre I'ONU et I'Union africaine en matière de paix et de sécurité sur le continent africain (2012) 39-40. Since the analysis of art 4(h) was not the main issue, the author simply discussed the principle of necessary authorisation. 
particular time in the world's history. Some aspects are no longer relevant in the world as it is today. That includes, for example, the notion of 'enemy state', which today has lost its meaning. Articles 53 and 107 of the Charter, to a certain extent, allow for measures against any state which during World War II had been an enemy of any signatory to the Charter. We cannot today imagine states or regional organisations deploying military actions against Germany or Japan on the basis of these two articles. The international scene has changed completely. Germany and Japan today are among the most significant financial contributors to the UN. The meaning of chapter VIII has also greatly evolved. This includes the notion of the 'maintenance of international peace and security', but also 'the co-operation between the UN and regional organisations under chapter VIII'.

As Yusuf wrote, '[t]he maintenance of peace and security among nations has evolved in recent years in the practice of the United Nations to encompass the protection of human security within nations'. ${ }^{39}$ A new concept has been born, namely, peacekeeping. The General Assembly, through Resolution $377(\mathrm{~V})$, received new powers in the area of peace and security. This plenary organ is the one that created the first peacekeeping mission of the ground (UNEF). As President Zuma of South Africa stated before the Security Council, '[the] AU has also sought to give practical meaning to the vision of the United Nations Charter on co-operation with regional organisations'. ${ }^{40}$ At the time the Charter was written, most armed conflicts were inter-state armed conflicts. However, the UN adapted the Charter and its implementation to the internal conflicts of today. It should, therefore, be accepted that an armed conflict taking place within one state threatens international peace and security. In addition, the Security Council has largely extended the notion to take into account situations that do not have an evident connection with peace and security. Kwakwa stated it as follows: ${ }^{41}$

The concept of 'security' has been given a very expansive definition in the last few years. It is now generally accepted that security threats are manifested not only in traditional military terms, but also through such problems as poverty, resource scarcity, and refuge and migration flows.

Recently, Germany brought the Security Council to debate the 'impact of climate change' on the maintenance of international peace and security. ${ }^{42} \mathrm{~A}$ month before Germany, Gabon had drawn the Council into a debate regarding the adoption of a second resolution

39 Yusuf (n 1 above) 11.

40 Statement of President Zuma (n 11 above) 3.

41 E Kwakwa 'Internal conflicts in Africa: Is there a right of humanitarian action?' (1994) 2 African Yearbook of International Law 34.

42 See PV/.6587, Record of the 6587th meeting of the Security Council; see also S/PRST/2011/15, the Presidential Statement adopted after that debate. 
on the 'impact of the HIV/AIDS epidemic on international peace and security'. ${ }^{43}$ This, again, demonstrates the fact that the Security Council has extended the notion of 'maintenance of international peace and security'.

The notion of 'co-operation between the UN and regional organisations' has also evolved. Where the UN did not have good relations with regional organisations during the Cold War era, this situation has changed completely since the 1990s. In 1992, the UN Secretary-General, Boutros Ghali, submitted a report, known as the 'Agenda for peace', to both the General Assembly and the Security Council. Three years later, he completed that report with a 'Supplement to an agenda for peace'. The Secretary-General recognised that ${ }^{44}$

[r]egional action as a matter of decentralisation, delegation and cooperation with United Nations efforts could not only lighten the burden of the Council, but also contribute to a deeper sense of participation, consensus and democratisation in international affairs.

This caused the UN Charter to be imbued with a consideration of the problems and opportunities of today. As AU leaders claim: ${ }^{45}$

A creative reading of the provisions of chapter VIII of the United Nations Charter to allow the African Union and its regional mechanisms for conflicts prevention, management and resolution to fully play their role as integral component of collective security.

Do African states reclaim this innovative and practical reading of chapter VIII so as to take into account their supposed willingness to intervene in accordance with article 4(h), even prior to authorisation by the Security Council?

\section{Understanding the intention of the founders of the $\mathrm{AU}$ with regard to article $4(\mathrm{~h})$}

As Maluwa described it, when the AU Constitutive Act was drafted, 'the implications of these provisions for the requirement of prior authorisation by the UN Security Council of enforcement action by regional organisations or arrangements under article 53 of the UN

43 S/RES/1983 (2011), Resolution of the Security Council adopted on 7 June 2011; see also S/PV.6547, Record of the 6547th meeting of the Security Council.

44 A/47/277-S/24111, An agenda for peace - Preventive diplomacy, peace making and peace keeping - Report of the Secretary-General pursuant to the statement adopted by the Summit Meeting of the Security Council on 21 January 1992, para 64.

45 S/PV.6702, Record of the 6702nd meeting of the Security Council on 12 January 2012, Statement of Mr Ramtane Lamamra, Commissioner for Peace and Security of the AU. See also the statement by President Zuma of South Africa at the same meeting. President Zuma states: 'The AU has also sought to give practical meaning to the vision of the United Nations Charter on co-operation with regional organisations.' 
Charter were not addressed in these debates'. Furthermore, the AU's legal adviser, Ben Kioko, wrote that 'when questions were raised as to whether the Union could possibly have an inherent right to intervene other than through the Security Council, they were dismissed out of hand'. ${ }^{46}$ It is evident that the issue of prior Security Council authorisation was not the main concern of African leaders when drafting this polemical measure. More clearly, in the 'Ezulwini Consensus', ${ }^{47}$ the AU stated that the UN General Assembly and Security Council were often far away from the scenes of conflict. Therefore, these UN bodies lacked the ability to undertake proper measures. Even if the $\mathrm{AU}$ recognised in this document that intervention by regional organisations should be undertaken with Security Council approval, it also relativised its speech and said that 'in certain situations, such approval could be granted "after the fact", in circumstances requiring urgent action'. ${ }^{48}$ To get a better understanding of this position, it is important to go back on the context that prevailed at the time of the negotiation and adoption of the AU Charter.

The former Organisation of African Unity (OAU) may be considered to be a successful organisation, according to the goals fixed in its Charter. Created in 1963 during a period when some African states had recently become independent and others were still fighting for independence, the OAU established purposes and principles corresponding to its time. Article II of its Charter contains five purposes. Two of these require the organisation to defend sovereignty, territorial integrity and the independence of African states, and to eradicate all forms of colonialism in Africa. Thereafter, the three first principles contained in article III are '(1) the sovereign equality of all member states; (2) non-interference in the internal affairs of states; and (3) respect for the sovereignty and territorial integrity of each state and for its inalienable right to independent existence'. Although these principles assisted the OAU to succeed with regard to the independence of territories, the end to apartheid and the territorial integrity of states, they soon became limited, and even became prejudicial and harmful, if not to African states, at least to African populations. As recognised by Kioko and others, the principle of non-interference did not allow the OAU to stop gross human right violations, such as those committed by Idi Amin in Uganda, or Bokassa in the Central African Republic in the 1970s. ${ }^{49}$ More importantly, the OAU failed to prevent or stop the Rwandan genocide of 1994. Kioko writes that the Assembly of the OAU became a kind of 'heads of state club', where each head of state avoided criticising one

$46 \quad$ Kioko (n 1 above) 821.

47 Ext/EX.CL/2 (VII), The Common African Position on the Proposed Reform of the United Nations: The 'Ezulwini Consensus'.

48 Common African Position (n 47 above) 6.

49 Kioko (n 1 above) 812. 
another. ${ }^{50}$ The passivity of the OAU under the guise of the principle of non-interference was criticised by everyone in Africa, including some heads of state. ${ }^{51}$ The OAU had succeeded in protecting African states and in defending their sovereignty, as established in its Charter. Yet, Africa needed another organisation that would protect the rights of its populations. The Charter of the AU which was then created proceeded from the principle of non-intervention to the right of intervention.

However, regardless of the fact that they themselves could not manage to protect their own populations, African leaders were frustrated by the UN, and the international community at large, for the way in which Africa's problems were being dealt with. The Charter of the OAU established the principle of non-interference, but it did not provide the organisation with a legal basis on which to deal with grave internal crises. The OAU could solve conflicts peacefully, but it did not give itself the means of using enforcement action. Thus, when massive human rights violations occurred in Uganda and the Central African Republic, and the Rwandan genocide took place, only the UN could intervene. However, the UN did nothing. In addition, African leaders felt that decisions on Africa were taken elsewhere, by people who did not care about Africa's problems. ${ }^{52}$ Therefore, they did not want to subordinate their right of intervention under an organ like the Security Council. Kioko stated it as follows: ${ }^{53}$

This decision reflected a sense of frustration with the slow pace of reform of the international order, and with instances in which the international community tended to focus attention on other parts of the world at the expense of more pressing problems in Africa.

This was the beginning of what has been conceptualised as 'African solutions to African problems', and described by Williams in these words: 54

Since the early 1990s, and particularly after the so-called Black Hawk Down episode in Mogadishu in October 1993, resulting in the death of eighteen US servicemen, several powerful Western states and a range of African governments have significantly altered their policies toward armed conflict in Africa.

50 Kioko 814

51 Kioko 813. The author mentions derisive statements by some heads of state who criticised the passivity of the OAU under the guise of the principle of noninterference. Among these are President Museveni of Uganda, who criticised the OAU as the organisation that failed to protect the lives of 75000 people in his country under the guise of the principle of non-interference; and President Aferwerki of Eritrea, who was of the view that the OAU was ineffective as it failed to protect the people of Eritrea.

52 Referring to the lack of interest in Africa after the Cold War.

53 Kioko (n 1 above) 821.

54 PD Williams 'Keeping the peace in Africa: Why "African" solutions are not enough' (2008) Carnegie Council for Ethics and International Affairs 310. 
The African continent, in effect, then seemed to be left to its own devices. ${ }^{55}$ A report from the Office for the Co-ordination of Humanitarian Affairs (OCHA) stated that '[t]he lesson of Rwanda for African leaders was that they "should no longer wait for action by the international community or the Security Council"'.56 This may help understand why African leaders did not find it necessary to request authorisation by the UN Security Council when they had to intervene in a situation, also while there was a perceived disinterest on the part of the Council. The right of intervention of the AU could be analysed as what Acharya described as 'norm subsidiarity': ${ }^{57}$ African states reacted to the 'tyranny', 'hypocrisy' and neglect by the UN during events of the 1970s and 1990s. The question is whether intervention by the AU without prior authorisation by the UN Security Council could be considered legal.

\section{Possible legality and legitimacy of intervention by the AU without UN Security Council authorisation}

Some commentators argue that article 53 of the UN Charter is a peremptory norm of general international law because of its connection with article 2(4), and that it is part of the UN Charter. But what is unacknowledged in this argument is that article 2(4) is not recognised as a jus cogens norm because it figures in the Charter. As Hossain stated, '[no] treaty, not even the Charter of the United Nations, can establish a rule of general international law' ${ }^{58}$ Article $2(4)$ is considered as jus cogens because the prohibition of threat or use of force existed before the adoption of the Charter and had already been universally accepted. ${ }^{59}$ As Brownlie stated, '[t]he Kellogg-Briand norm prohibiting war making had by 1939 become so well established as "to justify the assertion that a customary rule had developed"'.60 Therefore, it may be accepted that only article 2(4) is a jus cogens norm and not article 53. No legal document has recognised the question of authorisation by the Security Council as a peremptory norm of general international law. As for article 2(4), the article prohibits force against the territorial integrity or political independence of a state. We could then assert that the prohibition disappears with the consent of the states concerned. Yet, when

55 D O'Brien 'The search for subsidiarity: The UN, African regional organisations and humanitarian action' (2000) 7 International Peacekeeping 60.

56 Quoted by O'Brien (n 55 above) 63.

57 Acharya defines 'norm subsidiarity' as 'a process whereby local actors create rules with a view to preserving their autonomy from dominance, neglect, violation, or abuse by more powerful central actors'. See Acharya (n 12 above) 95-123.

$58 \mathrm{~K}$ Hossain 'The concept of jus cogens and the obligation under the UN Charter' (2005) 3 Santa Clara Journal of International Law 77-78.

59 Hossain (n 58 above) 88-89.

60 I Brownlie, International law and use of force by states (1963) 108-110, quoted by Hossain (n 58 above) 92. 
ratifying its Constitutive Act, member states of the AU agreed with its content, including article $4(\mathrm{~h})$, which gives the $A U$ the right to intervene to stop massive crimes and other human rights violations.

Moreover, as Kuwali pointed it out, article 4(h) could be based on the notion of 'responsibility to protect'. ${ }^{61} \mathrm{He}$ recalls that the UN General Assembly itself endorsed this notion at the World Summit. ${ }^{62}$ Indeed, the General Assembly recognises that, should states fail to protect their population, the Security Council could apply chapter VII to protect populations from genocide, war crimes, ethnic cleansing and crimes against humanity. On a case-to-case basis, appropriate regional organisations could intervene. ${ }^{63}$ If this does not imply that regional organisations could intervene without Council authorisation, another UN document could be of assistance. The question came from the Secretary-General of the UN: ${ }^{64}$

To those for whom the greatest threat to the future of international order is the use of force in the absence of a Security Council mandate, one might ask, not in the context of Kosovo but in the context of Rwanda, if, in those dark days and hours leading up to the genocide, a coalition of states had been prepared to act in defence of the Tutsi population, but did not receive prompt Council authorisation, should such a coalition have stood aside and allowed the horror to unfold?

In actual fact, the correct answer is no. This shows that the AU is not the only organisation that wants a creative reading of the Charter. Many others would agree that there could be an intervention pursuant to article 4(h) without prior authorisation by the Security Council. The reading of the Charter evolves continuously to adapt to the problems of the international community. It was in the same spirit that Resolution 377 (V) was adopted to allow the General Assembly to intervene in matters belonging to the competence of the Council when the latter is not able to react in a timely manner. According to this, it should be specified that the AU can apply article 4(h) without authorisation only when the Council does not react. In other words, should the Council expressly refuse authorisation, the AU must comply with such a refusal. However, it is difficult to imagine that the Council would expressly prohibit any form of intervention while grave circumstances, such as those described in article $4(\mathrm{~h})$ of the $A U$ Charter, prevail on the ground. The discussion then revolves around non-reaction by the Council. It is this situation that Borgen called 'the problem of deadlock'. ${ }^{65}$ As he wrote, the 'dilemma of deadlock arises when a regional organisation wishes to undertake an enforcement action but is unable to get Security Council approval'. If the Council

61 Kuwali (n 1 above).

62 Kuwali 62-64.

63 A/RES/60/1, 2005 World Summit Outcome - Resolution adopted by the General Assembly on 16 September 2005, para 139 .

64 A/54/PV.4, Statement of the Secretary-General, presenting his annual report to the General Assembly, 20 September 1999.

65 Borgen (n 19 above) 802. 
does nothing, and people are dying on the ground, the AU could legally intervene without prior authorisation by the Security Council. This would be the appropriate thing to do, since the AU would be stopping violations against peremptory norms of general international law, namely, genocide, war crimes and crimes against humanity. ${ }^{66}$

\section{Conclusion}

The article recognises the fact that the centralisation of force, in the hands of the Security Council, is crucial for the safety of the international community. Subsequently, any regional actor willing to use force should always request authorisation from the Security Council. This rule also applies to regional organisations such as the AU. Nevertheless, the article also acknowledges that if, due to a lack of unanimity among its members, the Security Council cannot pronounce itself on whether to give or to refuse such authorisation, while grave crimes such as those mentioned in article 4(h) of the AU Constitutive Act are taking place on the continent, the AU has a right to intervene and to put an end to genocide, war crimes or crimes against humanity.

However, having this right does not mean that the $A U$ would effectively use it. Like the OAU, the AU is still acting as a 'heads of state club'. Most African leaders lack national legitimacy, many of them elected in a dubious context with a minimal respect for their own national constitutions. Which of these leaders would use article 4(h) against a colleague? In some cases, such as in Darfur, Libya, Egypt, the Central African Republic or Burundi, the AU could have intervened, but it seems that the AU adopts a policy of prudence when it comes to using force. In this context, article 4(h) appears to be a mere political act of frustration, rather than a real ambition to protect civilians from grave atrocities committed by their leaders or other armed groups. We could, therefore, conclude that the AU has the right to intervene in accordance with article 4(h) without authorisation by the Security Council when the latter is unable to pronounce itself. However, the current context does not allow one to affirm that the AU effectively plans to use this right.

66 As Judge Cherif Bassiouni stated: 'The legal literature discloses that the following international crimes are jus cogens: aggression, genocide, crimes against humanity, war crimes, piracy, slavery and slave-related practices, and torture. Sufficient legal basis exists to reach the conclusion that all these crimes are part of jus cogens.' See C Bassiouni 'International crimes: Jus cogens and obligatio erga omnes' (1996) 59 Law and Contemporary Problems 68. Each of these crimes has also particularly been recognised as being against jus cogens. Eg, The ICJ recognised that the prohibition against genocide was a jus cogens norm that could not be reserved or derogated from. See 'Reservations to the Convention on Genocide, Advisory Opinion: IC] Report 1951' 15. 